\title{
Soil fertility management of rainfed rice fields in Bengkulu Province, Indonesia
}

\author{
Nurmegawati ${ }^{*}$, Wilda Mika Sari, Ahmad Damiri, Tri Wahyuni, Irma Calista, Yudi Sastro, \\ Yulie Oktavia, Yahumri, Yartiwi \\ Agricultural Institute for Assement and Development Bengkulu 38119, Indonesia
}

\begin{abstract}
Rice is a staple food for the Indonesian people and is a national strategic commodity for national food security. Rainfed area is a potential land to support national rice production, by improving soil management through balanced fertilization based on the soil characteristics . This study aims to determine the soil fertility and alternative management implemented in 2019 and 2020 in Sukaraja and Pondok Kelapa sub districts, Bengkulu Province. Soil fertility status for CEC, base saturation, $\mathrm{C}$-organic, total $\mathrm{P}$ and total $\mathrm{K}$ taken based on the classification of the value of the combination of these chemical properties. The results showed that the soil fertility status of the rainfed rice fields in Sukaraja and Pondok Kelapa sub districts was low. The limiting factors for soil fertility for Sukaraja sub district are alkaline saturation, total K-total and P-total for Pondok Kelapa sub district. The limiting factors are all elements related to nutrient status assessment, namely $\mathrm{CEC}$, base saturation, total $\mathrm{P}$, total $\mathrm{K}$ and C-organic. Alternative soil management is carried out in an integrated manner by providing balanced organic and inorganic fertilizers. The provision of soil amendments such as straw compost, manure, biochar and agricultural lime/dolomite, especially for acid reacting soils, aims at increasing soil fertility before fertilization is applied.
\end{abstract}

\section{Introduction}

Population growth from year to year continues to increase. The population of Indonesia in 2020 reaches 269.6 million people [1] and this followed by an increase in food needs. On the other hand, the area of irrigated paddy fields continues to decrease due to the land use conversion of paddy fields to non-agricultural use. The rate of land use conversion is about 96,500 ha year-1, while the rate of expansion of paddy fields is only about 20,000-30,000 ha year-1 $^{-1}[2]$. Therefore, it is necessary to find alternatives potential land.

Indonesia government has policy to expand rice growing areas by optimizing suboptimal land use, such as swamp land, upland, as well as rainfed land. Rainfed land commonly use for rice cultivation at least once a year, depends on rainfall [3]. The area of rainfed rice fields in Indonesia is about 4 million ha [4], 3.71 million hectares (45.7\% of the total paddy field), spread over Java, Nusa Tenggara, Sumatra, Kalimantan, and Sulawesi and about $33.4 \%$ of rainfed paddy fields can be planted twice [5].

* Corresponding author: nurmegawati400@gmail.com 
Rainfed rice field as sub-optimal land, faces many problems, particularly soil fertility, climate change, drought and rapid weed growth [6], loss of organic matter, physical degradation of soil, soil erosion and sedimentation, water scarcity and pollution [7]. Soil fertility of rainfed land usually classified as low because of low levels of nitrogen and potassium, moderate level of phosphorus availability and Cation Exchange Capacity. The rice productivity in rainfed land varies seasonally. In the dry season with limited irrigation rice productivity is only $3.20 \mathrm{t} / \mathrm{ha}$ [8] and in the rainy season ranges between 3.2 to $4.50 \mathrm{t}$ $\mathrm{ha}^{-1}[8,9,10]$.

The area of rainfed rice fields in Bengkulu Province is around 24,787 ha, 25.75\% of the total area of rice fields [11]. Sukaraja and Pondok Kelapa sub districts are sub-districts that have great potential in developing rainfed rice fields. This land has highly potential to become productive land if the soil fertility level is managed through balanced fertilization according to the soil characteristics. This study aims to determine the status of soil fertility and alternative management of rainfed rice fields.

\section{Research methods}

This research was conducted in 2019 and 2020 in Sukaraja and Pondok Kelapa sub districts, Bengkulu Province. A total of ten composite soil samples were taken from the two research sites. The soil samples were then analyzed at the Soil Laboratory of AIAT of Bengkulu. Observation parameters and measurement methods in the laboratory are presented in Table 1.

Table 1. Measured parameters and measurement methods [12]

\begin{tabular}{|c|c|}
\hline Soil analysis parameters & Measurement method \\
\hline Texture & Pipet \\
\hline $\mathrm{pH}\left(\mathrm{H}_{2} \mathrm{O}\right)$ & Electronic method \\
\hline $\mathrm{CEC}\left(\mathrm{cmol}(+) \mathrm{kg}^{-1}\right)$ & $\mathrm{NH}_{4} \mathrm{OAc} 1 \mathrm{~N} \mathrm{pH} \mathrm{7}$ \\
\hline $\mathrm{C}$-organic $(\%)$ & Walkey and black \\
\hline Exchangeable $\mathrm{K}\left(\mathrm{cmol}(+) \mathrm{kg}^{-1}\right)$ & Extract $\mathrm{NH}_{4} \mathrm{OAc} 1 \mathrm{~N} \mathrm{pH} \mathrm{7,}$ \\
\hline Exchangeable $\mathrm{Ca}$ and $\mathrm{Mg}\left(\mathrm{cmol}^{\circ}+\mathrm{kg}^{-1}\right)$ & Extract $\mathrm{NH}_{4} \mathrm{OAc} 1 \mathrm{~N} \mathrm{pH} \mathrm{7,}$ \\
\hline $\mathrm{N}$ total $(\%)$ & Kjeldahl \\
\hline $\mathrm{P}_{2} \mathrm{O}_{5}(\mathrm{mg} / 100 \mathrm{~g})$ & Extract $\mathrm{HCl} 25 \%$ \\
\hline $\mathrm{K}_{2} \mathrm{O}(\mathrm{mg} / 100 \mathrm{~g})$ & Extract $\mathrm{HCl} 25 \%$ \\
\hline
\end{tabular}

Assessment of soil fertility status is carried out by evaluating data on soil chemical properties. This assessment is only based on empirical soil chemical properties and has not been linked to crop requirements. The components of soil chemical properties that are used as the basis for determining soil fertility status were CEC, bas saturation, total $\mathrm{P}_{2} \mathrm{O}_{5}$, total $\mathrm{K}_{2} \mathrm{O}$ and C-organic. These chemical properties are used as the basis for assessment because they are closely related to soil fertility factors. Soil fertility status was determined based on the classification of the combined value of the chemical properties in Table 2. 
Table 2. Combination of soil chemical properties and soil fertility status [13,14,15]

\begin{tabular}{|c|c|c|c|}
\hline $\begin{array}{l}\text { Cation Exchange } \\
\text { Capacity (CEC) }\end{array}$ & $\begin{array}{c}\text { Base } \\
\text { saturation }\end{array}$ & $\begin{array}{c}\mathrm{P}_{2} \mathrm{O}_{5}, \mathrm{~K}_{2} \mathrm{O} \text { and } \mathrm{C}- \\
\text { organic }\end{array}$ & $\begin{array}{c}\text { Fertility } \\
\text { Status }\end{array}$ \\
\hline $\begin{array}{l}\mathrm{H} \\
\mathrm{H} \\
\mathrm{H} \\
\mathrm{H} \\
\mathrm{H} \\
\mathrm{H} \\
\mathrm{H}\end{array}$ & $\begin{array}{l}\mathrm{H} \\
\mathrm{H} \\
\mathrm{H} \\
\mathrm{H} \\
\mathrm{H} \\
\mathrm{H} \\
\mathrm{H}\end{array}$ & $\begin{array}{l}\geq 2 \mathrm{H} \text { without } \mathrm{L} \\
\geq 2 \mathrm{H} \text { with } \mathrm{L} \\
\geq 2 \mathrm{M} \text { without } \mathrm{L} \\
\geq 2 \mathrm{M} \text { with } \mathrm{L} \\
\mathrm{H} \mathrm{M} \mathrm{L} \\
\geq 2 \mathrm{~L} \text { with } \mathrm{H} \\
\geq 2 \mathrm{~L} \text { without } \mathrm{H}\end{array}$ & $\begin{array}{l}\text { High } \\
\text { Medium } \\
\text { High } \\
\text { Medium } \\
\text { Medium } \\
\text { Medium } \\
\text { Low } \\
\end{array}$ \\
\hline $\begin{array}{l}\mathrm{H} \\
\mathrm{H} \\
\mathrm{H} \\
\mathrm{H}\end{array}$ & $\begin{array}{l}\mathrm{M} \\
\mathrm{M} \\
\mathrm{M} \\
\mathrm{M}\end{array}$ & $\begin{array}{l}\geq 2 \mathrm{H} \text { without } \mathrm{L} \\
\geq 2 \mathrm{H} \text { with } \mathrm{L} \\
\geq 2 \mathrm{M} \\
\geq 2 \mathrm{~L} \text { without } \mathrm{H}\end{array}$ & $\begin{array}{l}\text { High } \\
\text { Medium } \\
\text { Medium } \\
\text { Low }\end{array}$ \\
\hline $\begin{array}{l}\mathrm{H} \\
\mathrm{H} \\
\mathrm{H}\end{array}$ & $\begin{array}{l}\mathrm{L} \\
\mathrm{L} \\
\mathrm{L}\end{array}$ & $\begin{array}{l}\geq 2 \mathrm{M} \text { without } \mathrm{L} \\
\geq 2 \mathrm{H} \text { with } \mathrm{L} \\
\text { Other combination }\end{array}$ & $\begin{array}{l}\text { Medium } \\
\text { Low } \\
\text { Low }\end{array}$ \\
\hline $\begin{array}{l}\mathrm{M} \\
\mathrm{M} \\
\mathrm{M}\end{array}$ & $\begin{array}{l}\mathrm{H} \\
\mathrm{H} \\
\mathrm{H} \\
\end{array}$ & $\begin{array}{l}\geq 2 \mathrm{H} \text { without } \mathrm{L} \\
\geq 2 \mathrm{M} \text { without } \mathrm{L} \\
\text { Other combination }\end{array}$ & $\begin{array}{l}\text { Medium } \\
\text { Medium } \\
\text { Low }\end{array}$ \\
\hline $\begin{array}{l}\mathrm{M} \\
\mathrm{M} \\
\mathrm{M} \\
\mathrm{M} \\
\mathrm{M}\end{array}$ & $\begin{array}{l}\mathrm{M} \\
\mathrm{M} \\
\mathrm{M} \\
\mathrm{L} \\
\mathrm{L}\end{array}$ & $\begin{array}{l}\geq 2 \mathrm{H} \text { without } \mathrm{L} \\
\geq 2 \mathrm{M} \text { with } \mathrm{L} \\
\text { Other combination } \\
3 \mathrm{H} \\
\text { Other combination }\end{array}$ & $\begin{array}{l}\text { Medium } \\
\text { Medium } \\
\text { Low } \\
\text { Medium } \\
\text { Low } \\
\end{array}$ \\
\hline $\begin{array}{l}\mathrm{L} \\
\mathrm{L} \\
\mathrm{L} \\
\mathrm{L}\end{array}$ & $\begin{array}{l}\mathrm{H} \\
\mathrm{H} \\
\mathrm{H} \\
\mathrm{H}\end{array}$ & $\begin{array}{l}\geq 2 \mathrm{H} \text { without } \mathrm{L} \\
\geq 2 \mathrm{M} \text { with } \mathrm{L} \\
\geq 2 \mathrm{M} \text { without } \mathrm{L} \\
\text { Othe combination }\end{array}$ & $\begin{array}{l}\text { Medium } \\
\text { Low } \\
\text { Medium } \\
\text { Low }\end{array}$ \\
\hline $\begin{array}{c}\mathrm{L} \\
\mathrm{L} \\
\mathrm{L} \\
\mathrm{ML}\end{array}$ & $\begin{array}{c}\text { M } \\
M \\
\text { L } \\
\text { HVL }\end{array}$ & $\begin{array}{l}\geq 2 \mathrm{H} \text { without } \mathrm{L} \\
\text { Other combination } \\
\text { All combinations } \\
\text { All combinations }\end{array}$ & $\begin{array}{l}\text { Medium } \\
\text { Low } \\
\text { Low } \\
\text { Very } \\
\text { low } \\
\end{array}$ \\
\hline
\end{tabular}

Note: $\mathrm{H}=$ High, $\mathrm{M}=$ Medium, $\mathrm{L}=$ Low, $\mathrm{VL}=$ Very low

\section{Results and discussion}

\subsection{Soil characteristics}

Soil is an essential natural resource that needs serious attention to avoid damage that can reduce productivity. The characteristics of rainfed rice fields in Sukaraja and Pondok Kelapa sub-districts of Bengkulu Province are presented in Table 3. Soil texture is classified as silty clay to clay. The soil texture is very suitable for rice fields. Rice plants are very suitable if the soil texture class is fine, namely sandy loam, clay and dusty clay [16]. Soil texture is closely related to water holding capacity, soil porosity, air and water movement, specific surface area, the ease of compaction of the soil. 
Table 3. Characteristics of rainfed paddy fields in Sukaraja and Pondok Kelapasub districts, Bengkulu Province

\begin{tabular}{|c|c|c|c|c|}
\hline \multirow{2}{*}{$\begin{array}{l}\text { Soil chemical and } \\
\text { physical properties }\end{array}$} & \multicolumn{2}{|c|}{ Sukaraja Sub district } & \multicolumn{2}{|c|}{$\begin{array}{c}\text { Pondok Kelapa Sub } \\
\text { district }\end{array}$} \\
\hline & Value & Criteria & Value & Criteria \\
\hline Texture & Silty clay & - & Clay & \\
\hline $\mathrm{pH}\left(\mathrm{H}_{2} \mathrm{O}\right)$ & 5.23 & Acid & 4.9 & Acid \\
\hline C-organic (\%) & 9.11 & Very high & 1.2 & Low \\
\hline $\mathrm{N}(\%)$ & 0.63 & High & 0.18 & Low \\
\hline $\mathrm{P}(\mathrm{ppm})$ & 1.01 & Very low & 3.4 & Very low \\
\hline $\begin{array}{l}\text { Exchangeable K } \\
\left(\mathrm{cmol}(+) \mathrm{kg}^{-1}\right)\end{array}$ & 0.20 & Low & 0.14 & Low \\
\hline $\begin{array}{l}\text { Exchangeable Na } \\
\left(\mathrm{cmol}(+) \mathrm{kg}^{-1}\right)\end{array}$ & 0.27 & Low & 0.52 & Medium \\
\hline $\begin{array}{c}\text { Exchangeable Ca } \\
\left(\mathrm{cmol}(+) \mathrm{kg}^{-1}\right)\end{array}$ & 0.22 & Low & 2.16 & Low \\
\hline $\begin{array}{l}\text { Exchangeable } \mathrm{Mg} \\
\left(\operatorname{cmol}(+) \mathrm{kg}^{-1}\right)\end{array}$ & 0.41 & Low & 4.32 & High \\
\hline $\mathrm{CEC}\left(\operatorname{cmol}(+) \mathrm{kg}^{-1}\right)$ & 17.79 & Medium & 9.09 & Low \\
\hline Base saturation & 6.18 & Very low & 78.55 & High \\
\hline Total P (HCl 25\%) & 13.40 & Very low & 6.0 & Very low \\
\hline Total K ( $\mathrm{HCl} 25 \%)$ & 5.36 & Very low & 9.5 & Very low \\
\hline
\end{tabular}

The acidity $(\mathrm{pH})$ of the rainfed soils in the two sub-districts is acidic, quite suitable for rice cultivation. The C-organic content in Sukaraja sub district is very high and low for Pondok Kelapa sub district. The $\mathrm{N}$ content was high and low in both sites. The content of $\mathrm{P}$, $\mathrm{K}$ and the availability of bases were very low to low, exchangeable $\mathrm{Na}$ was moderate, exchangeable $\mathrm{Mg}$ and base saturation is high. The nutrient content of $\mathrm{P}$ and $\mathrm{K}$ were very low, presumably due to the influence of the parent material and the influence of land management and the use of relatively low $\mathrm{P}$ and $\mathrm{K}$ fertilizers. In general, the chemical properties of rainfed soils in the two research sites were relatively low.

\subsection{Soil fertility status}

The determination of soil fertility status based on soil chemical properties, i.e. CEC, base saturation, total $\mathrm{P}_{2} \mathrm{O}_{5}$, total $\mathrm{K}_{2} \mathrm{O}$ and $\mathrm{C}$-organic. The results of the assessment of soil fertility status are shown in Table 3. Therefore, it can be seen that the results of the assessment of the fertility status of the study area are low.

Tabel 3. Soil fertility status of rainfed rice fields in Sukaraja and Pondok Kelapa sub district, Bengkulu Province

\begin{tabular}{|c|c|c|c|c|}
\hline \multirow{2}{*}{ Soil chemical properties } & \multicolumn{2}{|c|}{ Sukaraja sub district } & \multicolumn{2}{c|}{$\begin{array}{c}\text { Pondok Kelapa sub } \\
\text { district }\end{array}$} \\
\cline { 2 - 5 } & Value & Class & Value & Class \\
\hline $\mathrm{CEC}\left(\mathrm{cmol}(+) \mathrm{kg}^{-1}\right)$ & 17.79 & Medium & 9.09 & Low \\
\hline Base saturation $(\%)$ & 6.18 & Very low & 78.55 & High \\
\hline Total $\mathrm{P}_{2} \mathrm{O} 5(\mathrm{mg} / 100 \mathrm{~g})$ & 13.40 & Very low & 6.0 & Very low \\
\hline Total $\mathrm{K}_{2} \mathrm{O}(\mathrm{mg} / 100 \mathrm{~g})$ & 13.40 & Very low & 6.0 & Very low \\
\hline $\mathrm{C}$-organic $(\%)$ & 9.11 & Very high & 1.2 & Low \\
\hline Soil fertility status & \multicolumn{3}{|c|}{ Low } & \multicolumn{3}{c|}{ Low } \\
\hline
\end{tabular}

Table 3 shows that that the CEC in Sukaraja and Pondok Kelapa sub districts are medium and low. Soils with low CEC do not respond to fertilization. Soils with moderate 
CEC were more responsive to fertilization than soils with low CEC. In soils that have a higher CEC, less cation leaching will occur. Therefore, the addition of nitrogen and potassium to the soil is possible. The CEC value of the soil can be used as an indicator of the soil response to fertilization [15]. Soils with low CEC are generally unresponsive and efficient to fertilization. The base saturation in the two research sites were different, which was very low in Sukaraja research site, and high in Pondok Kelapa research site. This difference may influence the nutrient exchange process, and response to fertlization. The total $\mathrm{P}$ and $\mathrm{K}$ content in the study area were very low. The deficiency of phosphorus $(\mathrm{P})$ is one of the main limiting factors for plant growth and production. Plants requires $\mathrm{P}$ of $0.3 \%$ to $0.5 \%$ of their dry weight for optimal growth [17].

The content of C-organic is an element that can determine the level of soil fertility. In general, the C-organic content in the study area was very high and low. The content of Corganic is an element that can determine the level of soil fertility. The C-organic content in Sukaraja Sub District was very high, while in Pondok Kelapa sub district was low. The percentage of organic matter means showing the level of soil fertility. The organic matter usually closely related to the CEC value. If organic matter is high, CEC value is also high. The results of the assessment of the fertility status of the study area were low. Each nutrient status class provides specific information about the expected yield response. Low nutrient status (L) indicates that plants are very responsive to fertilizer application [15].

\subsection{Management of soil fertility status}

Based on the soil assessment, we found the limiting factors in soil management, as shown Table 4.

Table 4. Limiting factors of soil fertility and alternative management rainfed rice field managemet in 2 districts in Bengkulu Province.

\begin{tabular}{|c|c|c|}
\hline $\begin{array}{c}\text { Sub } \\
\text { distric }\end{array}$ & $\begin{array}{c}\text { Soil fertility limiting } \\
\text { factor }\end{array}$ & Alternative management of soil fertility \\
\hline Sukaraja & $\begin{array}{c}\text { Base saturation, Total } \\
\text { K and Total P }\end{array}$ & $\begin{array}{c}\text { Application of balanced organic and inorganic fertilizers. } \\
\text { Provision of soil improvement materials such as straw } \\
\text { compost, manure, biochar and agricultural lime/dolomite }\end{array}$ \\
\hline $\begin{array}{c}\text { Pondok } \\
\text { Kelapa }\end{array}$ & $\begin{array}{c}\text { CEC, base saturation, } \\
\text { Total K, Total P and } \\
\text { C organic. }\end{array}$ & $\begin{array}{c}\text { Application an integrated manner, by giving high dosage of } \\
\text { organic fertilizers and balance inorganic fertilizers. Provision } \\
\text { of soil improvement materials such as straw compost, manure, } \\
\text { biochar and agricultural lime/ dolomite }\end{array}$ \\
\hline
\end{tabular}

It can be seen that each research area has different fertility limiting factor. To overcome these factors, soil management can be carried out by looking for alternative improvements. Management starts from soil improvement using soil improving materials. The available soil improvement material near the rice fields is rice straw used directly or composted. The limiting factor of base saturation can be increased with alkaline cations through the addition of lime, both calcite and dolomite. Besides increasing base saturation, it can also increase soil $\mathrm{pH}$. Increasing soil $\mathrm{K}$ and $\mathrm{P}$ levels can be done by applying K-rich organic matter such as straw compost and P-rich organic matter such as poultry manure and guano or application of SP36 and $\mathrm{KCl}$ inorganic fertilizers according to plant needs.

Alternative soil management is carried out in an integrated manner, namely the provision of balanced organic and inorganic fertilizers. Recommendations for inorganic fertilizers can be made based on the status of $\mathrm{P}$ and $\mathrm{K}$ nutrients, which are submitted to the Minister of Agriculture No. 40/Permentan/OT.140/04/2007 [18], then fertilizer recommendations can be drawn up. $\mathrm{P}$ and $\mathrm{K}$ nutrient status in Sukaraja and Pondok Kelapa 
sub-districts are very low, so fertilizer recommendations for both sub-districts are NPK 15$15-15250 \mathrm{~kg} \mathrm{ha}^{-1}$, Urea $150 \mathrm{~kg} \mathrm{ha}^{-1}$ and $\mathrm{KCl} 50 \mathrm{~kg} \mathrm{ha}^{-1}$.

There are many alternatives that can be done to increase the productivity of rainfed rice field. By giving biosilica fertilizer it can increase rice productivity by $1.08 \mathrm{tha}^{-1}$ in the dry season and up to $1.92 \mathrm{t} \mathrm{ha}^{-1}$ in the rainy season [19], fertilizer recommendations can be used $5 \mathrm{t} \mathrm{ha}^{-1}$ Biochar rice husk (RHB) and 50\% controlled release fertilizer [20]. Balanced fertilization technology that can be applied to rainfed lowland rice fields are Urea 250-300 $\mathrm{kg}$ ha-1, SP-36 50-75 kg ha-1, and $\mathrm{KCl} 50 \mathrm{~kg} \mathrm{ha}^{-1}$, providing organic material at least $2 \mathrm{t} \mathrm{ha}{ }^{-}$ 1 , and the return of the remaining crop straw to the ground. Balanced fertilization can increase rice yield from 1.8-3.5 $\mathrm{t} \mathrm{ha}^{-1}$ to $5.0-5.8 \mathrm{t} \mathrm{ha}^{-1}$ [9]. The most profitable fertilizer recommendation in Fogera, Northwest Ethiopia is $7.5 \mathrm{t} \mathrm{ha}^{-1}$ of manure combined with 120 $\mathrm{kg} \mathrm{N} \mathrm{ha}{ }^{-1}$ and $100 \mathrm{~kg} \mathrm{P}_{2} \mathrm{O}_{5} \mathrm{ha}^{-1}[6]$.

Other land management alternatives can be guided by fertilizer recommendations with an integrated planting calendar available for sub-districts throughout Indonesia. For instance, based on information from integrated KATAM, fertilizer recommendations for Sukaraja and Pondok Kelapa sub-districts are NPK $200 \mathrm{~kg} \mathrm{ha}^{-1}$ and urea $150 \mathrm{~kg} \mathrm{ha}^{-1}$ without the addition of organic matter. In contrast, with the addition of $2 \mathrm{tha}^{-1}$, the dosage of inorganic fertilizers is NPK $175 \mathrm{~kg} \mathrm{ha}^{-1}$ and urea $125 \mathrm{~kg} \mathrm{ha}^{-1}$ [21], with the addition of a minimum of $2 \mathrm{t} \mathrm{ha}^{-1}$ organic matter, and the remaining harvested straw is returned to the soil.

\section{Conclusions}

The soil fertility status of the rainfed rice fields in Sukaraja and Pondok Kelapa Sub districts was low. The limiting factors for soil fertility for Sukaraja sub district are base saturation, total $\mathrm{K}$ and total $\mathrm{P}$ for Pondok Kelapa sub district. The limiting factors are all elements related to nutrient status assessment, namely CEC, base saturation, Total P, Total $\mathrm{K}$ and $\mathrm{C}$-organic. Alternative soil management is carried out in an integrated manner by providing balanced organic and inorganic fertilizers. The provision of soil amendments such as straw compost, manure, biochar and agricultural lime/dolomite, especially for acid reacting soils, aims at increasing soil fertility before fertilization is applied.

Acknowledgments. The authors acknowledged the research from the head office of Assessment Institute of Agriculture Technology of Bengkulu and all member of research team.

\section{References}

1. Badan Pusat Statistik, Jumlah Penduduk Hasil Proyeksi Menurut Provinsi dan Jenis Kelamin (Ribu Jiwa), 2018-2020 (BPS, 2020)

2. A. Mulyani, D. Kuncoro, D. Nursyamsi, F. Agus, J. Tanah dan Iklim. 40, 2 (2016)

3. E. Tando, M. Asaad, J. Pengkaj. dan Pengemb. Teknol. Pertan. 23, 1 (2020)

4. A.A. Sulaiman, P. Simatupang, I. Las, Hermanto, I.K. Kariyasa, Syahyuti, S. Sumaryanto, Suwandi, K. Subagyono, Sukses Swasembada: Indonesia Menjadi Lumbung Pangan Dunia 2045 (Kementerian Pertanian, Jakarta, 2017)

5. A. Kasno, T. Rostaman, D. setyorini. J. Tanah dan Iklim. 4, 20 (2016)

6. S.A.N. Aryawati, W. Sunanjaya, I.M.R. Yasa, A.A.N.B. Kamandalu, A.R.K. Sari, Growth and productivity responses to the utilization of superior rice varieties and biosilica application in rainfed land, in IOP Conf. Series: Earth and Environmental Science, 653 (2021) 
7. G.R. Pratiwi, E. Hanudin, B.H. Purwanto, E. Sulistyaningsih, K. Hayashi, Rice growth response to $C R F$ fertilizer and biochar in rainfed land under two continuous seasons, In IOP Conf. Series: Earth and Environmental Science, 752, 1 (2021)

8. U. Susanto, S. Arifin, W. R. Rohaeni, R. H. Wening. J. Penelit. Pertan. Tanam. Pangan. 4, 2 (2020)

9. A. Kasno, D. Setyorini, I.W. Suastika. J. Sumberd. Lahan. 14, 1, 15-24 (2020)

10. A. Wihardjaka, A.A. Pramono, M.T. Sutriadi, J. Sumberd. Lahan. 14, 1 (2020)

11. Yartiwi, A. Damiri1, I.C. Siagian, H. Iswadi, Keragaan hasil varietas unggul baru (VUB) padi sawah lahan sawah tadah hujan pada dua musim tanam yang berbeda di Kabupaten Seluma Provinsi Bengkulu, in Prosiding seminar nasional lahan suboptimal 2018, 18-19 Oktober 2018, Palembang (2018)

12. Badan Penelitian dan Pengembangan Pertanian, Petunjuk Teknis Analisa Kimia Tanah, Tanaman, Air dan Pupuk (Badan Litbang Pertanian, 2012)

13. T. Wahyuni, H. Kusnadi, L. Ivanti, Evaluasi status kesuburan tanah sawah desa tebing kaning kabupaten bengkulu utara, in Prosiding Seminar Nasional Lahan Suboptimal ke-8 Tahun 2020, 20 Oktober 2020, Palembang (2020)

14. D.A.G. Widyantari, K.D.T. Kusmawati, J. Trop. Agroecotechnology. 4, 4 (2015)

15. A.N. Susanto, J. Pengkaj. dan Pengemb. Teknol. Pertan. 8, 3 (2005)

16. S. Ritung, K. Nugroho, A. Mulyani, E. Suryani, Petunjuk Teknis Evaluasi Lahan Untuk Komoditas Pertanian (Edisi revisi) (2011)

17. A.N. Flatian, S. Slamet, A. Citraresmin. J. Tanah dan Iklim. 42, 2 (2018)

18. M. Yusron, R.S. Wati, D. Setyorini, H. Mutmainah, J. Pengkaj. dan Pengemb. Teknol. Pertan. 20, 2 (2018)

19. G.R. Pratiwi, E. Hanudin, B.H. Purwanto, E. Sulistyaningsih, K. Hayashi, Rice growth response to CRF fertilizer and biochar in rainfed land under two continuous seasons, in IOP Conf. Series: Earth and Environmental Science, 752 (2021)

20. T.F. Tilahun, D.R. Nigussie, B. Wondimu, G. Setegn, Am. J. Res. Commun. 1, 4 (2013)

21. Badan Litbang pertanian, SI Katam terpadu versi 3.2 (2021) 